\title{
沖縄在来種，沖縄肉用種及び日本サーネン種山羊における 体重と体型間の関係の主成分分析
}

\author{
笹沼清孝*, 寺田直樹*, 新城明久*
}

\section{Principal Components Analysis of the Relationship between the Body Weight and the Body Feature in the Okinawa Native, the Okinawa Meat and the Japanese Saanen Goats}

\author{
Kiyotaka SASANUMA, Naoki TERADA and Akihisa SHINJO
}

College of Agriculture, University of the Ryukyus, 1 Senbaru, Nishiharacho, Okinawa 903-01, Japan

\section{Sammary}

The twelve body measurements in female goats of the three breeds such as the Okinawa Native, the Okinawa Meat and the Japanese Saanen breeds were examined by the principal components analysis. Each data were obtained from the area of the Ryukyu islands. The first and second principal components in the three breeds were $79.6 \%$ and $4.4 \%$, respectively. The first principal component reflected the body sizes, and the body features of the front quarters and the body height. In the classified data, the score of the first one was small in the Native breed, but large in the Saanen. The second one was indicated a small value through the three breeds.

The present study showed that the differences between the native and the Saanen breeds could be demonstrated by the principal component analysis, but could not between the Okinawa Meat and other two breeds.

主成分分析は, 多変量を少数の特性值に要約する ことができる。この手法が家畜に適用され，複数の 部位の体型測定値から体型を数量化し, 牛 ${ }^{1,2,3.5 .7 .9)}$, 馬 $^{10,11,13)}$ 及U゙犬(6)の品種の比較, 類型化及び体型の違

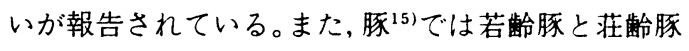
の比較が行われている。しかし、本邦において山羊 の品種の違いによる主成分分析は行われていない。 そのため, 本研究では沖縄在来種, 沖縄肉用山羊及 び日本ザーネン種の成雌の体重及び体型測定値に主 成分分析を適用することにより, 体型の品種間比較
を行った。

\section{材料及び方法}

分析デー夕は前報 ${ }^{12)}$ の測定値を用い, それらの測 定値に主成分分析を適用した。主成分の測定は，体 重と体型測定值の単位が異なるため, それらの相関 行列に基づく分析法陵を適しこれより求めた。主 成分分析の結果, 算出された各個体の主成分得点は, 平均 0 , 分散 1 に標準化され, 品種毎に平均值及び 標準偏差を求め，品種間の比較を行った。さらに， 主成分により座標上に，個体毎の主成分得点をプロ ットした。なお，分析は，芳賀4)が作成した microCDA プログラムで行った。 


\section{結果}

山羊の体型の品種間比較を行うため, 在来種, 沖 縄肉用山羊及び日本ザーネン種の体重及び12部位の 体型測定値の相関行列について主成分分析を行った。 その結果, 得られた第 1 及び第 2 主成分の因子負荷

量, 固有值及び奇与率を表 1 に示した。

奇与率は第 1 主成分が $79.6 \%$ ，第 2 主成分が 4.4 \%であり，第 1 と第 2 主成分を合計した累積寄与率 は $84.0 \%$ であった。第 1 主成分の因子負荷量は 0.795 から0.941の範囲で高く推移していた。このことか ら，第 1 主成分は体格の大小を对比する大きさ因子 (Size factor) と解釈された。第 2 主成分の因子負 荷量は正と負の値が認められ, 胸幅が 0.367 , 屃端幅 が0.356, 十字部高がー0.319及び体高がー0.317であ った。これより，第 2 主成分は前躯の幅が広く，背 が低い個体と前躯の幅が狭く, 背が高い個体を対比 する形因子（Shape factor）と解釈した。

算出された第 1 及び第 2 主成分の主成分得点は,

Table 1. Factor-loading and eigenvalue of two principal components for thirteen body measurements from the female goats of the Okinawa Native, the Okinawa Meat and the Japanese Saanen

\begin{tabular}{|c|c|c|}
\hline \multirow{2}{*}{ Item } & \multicolumn{2}{|c|}{ Factor-loading } \\
\hline & First & Second \\
\hline Withers height & 0.911 & -0.317 \\
\hline Hip height & 0.894 & -0.319 \\
\hline Body length & 0.941 & -0.064 \\
\hline Shoulder point width & 0.846 & 0.356 \\
\hline Chest width & 0.795 & 0.367 \\
\hline Chest depth & 0.906 & -0.043 \\
\hline Hip width & 0.880 & 0.096 \\
\hline Thurl width & 0.917 & -0.090 \\
\hline Pin bone width & 0.816 & -0.194 \\
\hline Rump length & 0.918 & -0.058 \\
\hline Chest girth & 0.940 & 0.146 \\
\hline Cannon circum & 0.885 & 0.006 \\
\hline Body weight & 0.933 & 0.158 \\
\hline Eiginvalue & 10.343 & 0.574 \\
\hline$\%$ & 79.6 & 4.4 \\
\hline
\end{tabular}

$\%$ : Percentage accounted for total variation by the principal component.
品種毎に平均値, 標準偏差及び品種間比較を表 2 に 示した。第 1 主成分は在来種がー1.075, 沖縄肉用山 羊がー0.279，日本ザーネン種が1.248で各品種間に は $5 \%$ \%ベルの有意差が認められた。第 2 主成分に は各品種間に有意差は認められなかった。

各品種の体型の変異をみるために，第 1 及び第 2 主成分による座標上に主成分得点をプロットしたも のが図 1 であった。第 1 主成分を座標軸上に投影す ると，在来種は全て負の位置に分布していた。日本

Table 2. Means and standard deviations for two principal component scores in the female goats of the Okinawa Native, the Okinawa Meat and the Japanese Saanen

\begin{tabular}{lcc}
\hline \multirow{2}{*}{ Item } & \multicolumn{2}{c}{ Principle component score } \\
\cline { 2 - 3 } & First & Second \\
\hline $\begin{array}{l}\text { Okinawa } \\
\text { Native }\end{array}$ & $-1.075^{\mathrm{a}} \pm 0.456^{*}$ & $0.001 \pm 0.780$ \\
$\begin{array}{l}\text { Okinawa } \\
\text { Meat }\end{array}$ & $-0.279^{\mathrm{b}} \pm 0.613$ & $0.074 \pm 0.991$ \\
$\begin{array}{l}\text { Japanese } \\
\text { Saanen }\end{array}$ & $1.248^{\mathrm{c}} \pm 0.519$ & $-0.146 \pm 1.139$ \\
\hline
\end{tabular}

* Mean \pm S.D.

a,b,c Means in the same column with different superscripts differ significantly $(p<0.05)$.

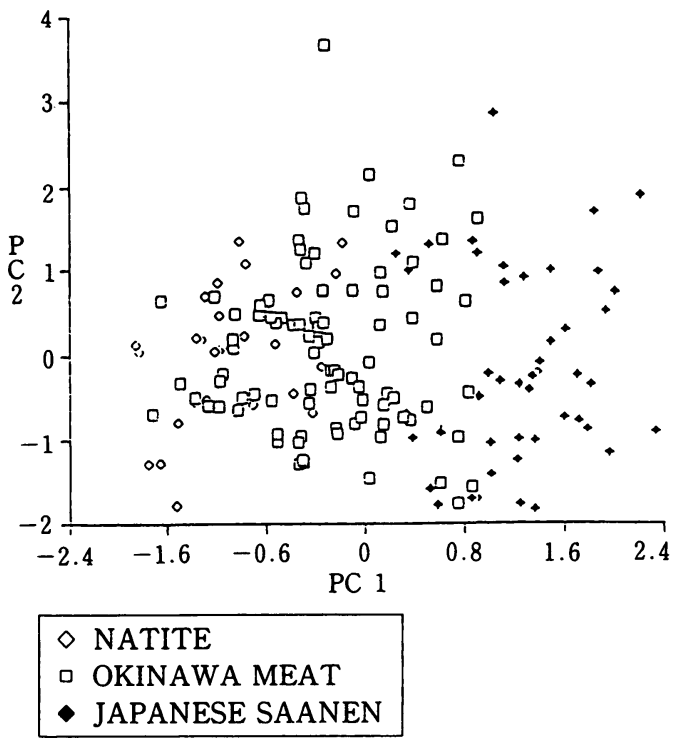

Fig. 1 Principal component chart of the first (PC 1) and second (PC 2) transformed variables 
ザーネン種は全て正の位置に分布しており，在来種 との判別が可能であった。沖縄肉用山羊は原点付近 を中心に分布し，在来種の全体と日本ザーネン種の 一部に分布が重なっていた。そのため，沖縄肉用山 羊は他の 2 品種との判別が困難であった。第 2 主成 分を座標軸上に投影すると，3品種とも分布が重な ク判別ができなかった。

\section{考察}

山羊の体重及び体型測定值を主成分分析した結果, 第 1 主成分は大きさに関する因子, 第 2 主成分は形 態に関係する因子と解釈された。これは, 牛 ${ }^{1,2,3,1}$, 馬 ${ }^{10,11,13)}$ 及び犬(6)の体型測定值を主成分分析した場 合の解釈と類似していた。寄与率は第 1 主成分が $79.6 \%$ と高く, 体重及び12部位の各体型測定值の情 報が良く説明されている。

在来種と日本ザーネン種は, 図 1 より判別が可能 であった。これは，第 1 主成分すなわち体格による ものであり，第 2 主成分を座標軸上に投影すると在 来種は日本ザーネン種の変異に含まれ, 体型による 判別はできなかった。在来種に日本ザーネン種を交 配した雑種集団である沖縄肉用山羊の変異は, 在来 種の変異のほぼ全体を含んでいたが，日本ザーネン 種の変異とはその一部が重なるだけだった。このた め, 沖縄肉用山羊と他の 2 品種との間の判別はでき なかった。さらに，第 1 主成分の主成分得点の平均 值は, 品種間に有意差が認められた。従って, 沖縄 肉用山羊の体格は日本ザーネン種より在来種に近く, 変異も大きいと考えられた。これは，体型測定值の 比較より得た結果と同样であり，その原因は日本ザ 一ネン種が腰麻に弱いことがあげられ，沖縄では日 本ザーネン種も肉用であり，分婏後搾乳は行わず， 乳房炎にかかる個体が多いことから日本ザーネン種 に近い個体に淘汰される割合が高いためと報告 ${ }^{14)}$ れている。他方, 第 2 主成分の主成分得点の平均值 は品種間に有意差が認められず，体型に関して品種 による特徵は認められなかった。

在来種, 沖縄肉用山羊及び日本ザーネン種からの 測定値に主成分分析を適用した結果，山羊の体格を 対比する第 1 主成分は奇与率电高く, 品種間の違い をある程度説明可能であった。しかし，体型を対比 する第 2 主成分は各品種とも変異が大きいため, 品 種間の違いを判別できなかった。

第 1 及び第 2 主成分の散布図により，在来種は小 型であり, 日本ザーネン種は大型の体型を示し, 両
品種の違いは顕著であり，明らかに区別できた。し かし, 沖縄肉用山羊は在来種と日本ザーネン種との 交雑型であるが，また充分に肉用種として独自に選 抜されていなかったため, 在来種と日本ザーネン種 の両品種間にその分布が広がり，その特異的な分布 が明確に区分できなかったと考えられた。

\section{約}

在来種，沖縄肉用山羊及び日本ザーネン種の体型 を比較するため, 体重及び体型測定値の相関行列に 主成分分析を適用した。得られた結果から，寄与率 は第 1 主成分が $79.6 \%$ ，第 2 主成分が $4.4 \%$ であっ た。第 1 主成分は大きさに関する因子，第 2 主成分 は形態に関する因子と解釈された。主成分得点は, 第 1 主成分では日本ザーネン種が大きく，在来種が 小さかった。第 2 主成分には有意差が認められなか った。以上のことから，第 1 及び第 2 主成分得点の 散布図から，在来種と日本ザーネン種は判別が可能 であったが, 沖縄肉用山羊と他の 2 品種との判別は 不可能であった。

\section{引用文献}

1) Brown, J.E., Brown, C.J. and Butts. W.T. : Evaluating relationships among immature measures of size, shape and performance of beef bulls. I. Principal components as measures of size and shape in young Herford and Angus bulls. J. Anim. Sci., 36, 1010-1020, 1973.

2) Brown, C.J., Brown, J.E. and Butts, W.T. : Evaluating relationships among immature measures of size, shape and performance of beef bulls. II. The relationships between immature measures of size, shape and feedlot traits in young beef bulls. J. Anim. Sci., 36, 1021-1031, 1973.

3 ) Carpentre, Jr.J.A., Fitzhugh,H.A., Cartwright, T.C. Thomas,R.C. and Melton,A.A. : Principal components for cow size and shape. J. Anim. Sci., 46, 370-375, 1978.

4 ) 芳賀敏郎: 多変量解析入門-micro-CDA ? ニュアルー。 日科技連, 東京, 1986 .

5 ) Hayashi, Y., Otsuka, J. and Nishida,T. : Multivariate craniometrics of wild Banteng, Bos banteng, and five types of native cattle in 
Eastern Asia. Jpn. J. Zootech. Sci., 59, 660$672,1988$.

6 ）伊藤慎一：主成分分析による日本犬 6 犬種の体 型の比較。在来家畜研究会報告, 9, 130-138, 1980.

7 ) Ogawa, Y., Daigo, M. and Amasaki, H.: Craniometrical estimation of the Native Japanese Mishima Cattle, using multivariate analysis. Anat. Anz., 168, 197-203, 1989.

8 ）奥野忠一・久米 均・芳賀敏郎-吉沢 正: 多 変量解析法. 改訂版, 25-157, 日科技連, 東 京, 1986.

9）大塚閏一・並河鷹夫・野澤 謙：東アジアの在 来牛および野生バンテンの体型測定值について の主成分析. 日畜会報, $55,174-182,1984$.

10）笹沼清孝・新城明久：九州在来馬の類型化. 獣
医科学と統計利用, 13，1-6, 1984.

11）笹沼清孝・新城明久：主成分分析による沖縄在 来馬と宮古在来馬の体型に関する解析. 日畜会 報，57，705-711， 1986.

12）笹沼清孝・寺田直樹・新城明久：沖縄在来種, 沖縄肉用種及び日本サーネン種山羊における体 重と体型間の関係の重回帰分析. 獣医情報科学 誌, 30, 13 16, 1993.

13）新城明久・笹沼清孝：トカラ馬の体型に関する 主成分分析。琉大農報，32，99-102，1985.

14）新城明久・宮城 満・下地孝志: 沖縄肉用ヤギ の飼養実態，外部形態的遣伝形質および体型. 日畜会報，49，413４19，1978.

15）新城明久. 寺田直樹・笹沼清孝・古田賢治：豚 の成長に伴う体型測定值に对する主成分分析。 琉大農報, 38, 13〜16, 1991. 